\title{
MENTORSHIP GEREJA DALAM MEMBENTUK KARAKTER REMAJA DI BNKP JEMAAT HILIOMASIO MEDAN
}

\author{
Yunardi Kristian Zega \\ Universitas Kristen Indonesia. Jl. Mayjen Sutoyo No.2, RT.9/RW.6, Cawang, \\ Kec. Kramat jati, Kota Jakarta Timur, Daerah Khusus Ibukota Jakarta 13630 \\ Email: yunardichristian@gmail.com
}

\begin{abstract}
ABSTRAK
Perkembangan zaman semakin cepat berubah, seiring ditandai dengan banyaknya teknologi yang diciptakan oleh manusia. Di satu sisi teknologi membawa banyak pengaruh posisitif untuk mempermudah kehidupan manusia. Namun di sisi lainnya, teknologi juga dapat berakibat negatif, bagi orang-orang yang salah dalam penggunaannya. Salah satu dampak negatif dari perkembangan teknologi sekarang ini, dapat dilihat dari semakin banyaknya kasuskasus kenakalan di kaum remaja. Oleh sebab itu, banyak orang tua yang akhirnya bingung dan tidak tahu harus berbuat apa, akibat pengaruh teknologi digital yang telah merusak karakter kaum remaja, khususnya bagi kaum remaja di BNKP Jemaat Hiliomasio Medan. Untuk memecahkan permasalahan tersebut, peneliti menggunakan penelitian kualitatif dengan menggunakan metode pendekatan deskriptif. Di mana peneliti terjun langsung ke dalam lapangan sehingga dapat menemukan data yang akurat dan dapat dipertanggung jawabkan. Adapun hasil dari penelitian ini, antara lain: 1) pelaksanaan mentorship gereja terhadap Pendidikan Agama Kristen dalam Keluarga masih perlu untuk lebih ditingkatkan lagi, 2) gereja perlu untuk memberikan perhatian yang lebih serius terhadap pengajaran Pendidikan Agama Kristen bagi semua jemaat, dan 3) pelaksanaan Pendidikan Agama Kristen dalam Keluarga terhadap upaya membentuk karakter remaja di era digital, masih terlihat sangat kurang.
\end{abstract}

Kata Kunci: gereja; karakter remaja; keluarga; mentorship; pendidikan agama kristen

\section{ABSTRACT}

The times are changing rapidly, along with the many technologies created by humans. On the one hand, technology brings many positive influences to facilitate human life. But on the other hand, technology can also have negative consequences for people who use it incorrectly. One of the negative impacts of today's technological developments, can be seen from the increasing number of delinquency cases among adolescents. Therefore, many parents are confused and don't know what to do, due to the influence of digital technology that has damaged the character of teenagers, especially for teenagers in BNKP Congregation Hiliomasio Medan. To solve this problem, researchers used qualitative research using a descriptive approach method. Where researchers go directly into the field so that they can find accurate and accountable data. The results of this research include: 1) the implementation of church mentorship on Christian Religious Education in the Family still needs to be further improved, 2) the church needs to give more serious attention to the teaching of Christian Religious Education 
for all congregations, and 3) implementation Christian Religious Education in the Family towards efforts to shape the character of adolescents in the digital era, still looks very lacking.

Keywords: youth character; church; christian education; family; mentorship

\section{PENDAHULUAN}

Teknologi diciptakan untuk mempermudah kehidupan manusia dalam menjalankan berbagai kegiatan, seperti mempermudah mendapat informasi, komunikasi antarsesama, mendapat sumber pengetahuan, pekerjaan/usaha (bisnis) dan lain sebagainya. (Wawan Setiawan, 2017) menjelaskan, ada beberapa dampak yang dapat dirasakan dari perkembangan era digital, dampak positifnya antara lain: memudahkan informasi, memudahkan pekerjaan, mudahnya mendapat sumber belajar dalam segala bidang pendidikan, dan banyaknya toko online yang menyediakan berbagai macam kebutuhan. Selain itu, era digital juga membawa dampak yang negatif dalam kehidupan manusia, antara lain: mudahnya melakukan kecurangan (plagiatis), menjadikan seseorang suka berpikir pintas, berpikir pendek, dan kurang konsentrasi, menurunnya moralitas dengan penyalahgunaan pengetahuan seperti hackers, dan penyalahgunaan teknologi informasi sepeti melakukan penipuan.

Perkembangan teknologi bukan hanya menjangkit orang dewasa, anak-anakpun juga terkena imbasnya. (Ratnaya, 2011) menjelaskan, secara khusus dampak negatif dari perkembangan teknologi bagi anak-anak, antaranya lain; menghabiskan banyak waktu anak dengan percuma daripada melakukan hal-hal yang lebih bermanfaat seperti belajar atau olahraga, membuat anak tidak dapat berbaur dengan lingkungannya karena sudah nyaman dengan kehidupan onlinenya, melakukan pelanggaran Hak Cipta, Hak Kekayaan Intelektual (HaKI), melakukan kejahatan melalui media internet, menyebarkan virus komputer, memudahkan anak mengakses situs-situs pornografi, perjudian, tayangan kekerasan dan lainnya.

Berdasarkan data terbaru dari We Are Social di tahun 2020. Ada sebanyak 175,4 juta pengguna internet di Indonesia, kalau dibandingkan dengan tahun sebelumnya ada peningkatan sebesar 17\%. Berdasarkan jumlah keseluruhan dari populasi masyarakat Indonesia saat ini, ada sebanyak 64\% masyarakat Indonesia yang telah merasakan akses internet. Dalam laporan ini juga menjelaskan, masyarakat Indonesia yang memiliki ponsel ada sebanyak 338,2 juta dan ada 160 juta pengguna aktif internet. Bila 
dibandingkan dengan tahun 2019, maka di tahun 2020 ada peningkatan 10 juta orang Indonesia yang aktif sebagai pengguna internet (Haryanto, 2020).

Peningkatan dari jumlah pengguna internet juga berpengaruh terhadap sebagian kasus dari kenakalan remaja saat ini. Contohnya, kasus yang terjadi pada tanggal 20 Desember 2019, di mana terdapat 101 anak remaja di Kota Surabaya, Jawa Timur, yang putus sekolah serta terlibat tawuran dan kenakalan remaja lainnya, akibat pengaruh media sosial yang mereka gunakan (Basyari, 2019) Kasus yang terjadi di Pontianak, Kalimantan Barat pada tanggal 11 April 2019. Di mana media sosial mempunyai pengaruh besar dalam kasus penganiayaan dan perundungan terhadap siswi sekolah menengah pertama (SMP) yang berinisial A dengan usia 14 tahun (Sulistyo, 2019). Pada tanggal 12 September 2019 ada sebanyak 71 pelajar dari enam SMK di wilayah Bogor, Jawa Barat, membolos massal dengan tujuan ingin pergi bersama-sama ke Candi Borobudur di Magelang, Jawa Tengah (Wicaksono, 2019) Kenakalan remaja tersebut, terjadi akibat pengaruh dari perkembangan teknologi, melalui media sosial yang di miliki oleh remaja.

Berdasarkan data mengenai kasus kenakalan remaja yang terjadi di atas, untuk itu sangat penting memberikan pendidikan yang tepat bagi kaum remaja. Dengan memberikan pendidikan yang tepat dan sesuai dengan kebutuhan mereka, maka remaja tidak akan mudah terjerat ke dalam kasus-kasus kenakalan remaja seperti yang terjadi sekarang ini, khususnya akibat penggunaan teknologi. Oleh karena itu, keluarga merupakan salah satu tempat terbaik untuk memberikan pendidikan bagi setiap anak.

Di dalam Alkitab, keluarga merupakan lembaga pertama yang Allah berikan untuk membentuk karakter anak melalui orang tuanya. Dengan kata lain, Allah mengkehendaki agar anak belajar dari orang tuanya (U1. 6:7). Oleh karena itu, pendidikan agama Kristen di dalam keluarga (PAK Keluarga) harus memberikan kontribusi terhadap pembentukan karakter anak sehingga anak dapat bertumbuh semakin dewasa sesuai dengan ajaran iman Kristen (Ritonga \& Rantung, 2018) Jadi dapat disimpulkan bahwa, PAK Keluarga masa kini merupakan tugas orang tua untuk membimbing dan mengajar anak-anak agar dapat memiliki karakter hidup yang sesuai dengan ajaran iman Kristen, sehingga anak-anak tersebut juga tidak harus kehilangan identitasnya sebagai orang Kristen akibat pengaruh dari perkembangan zaman. 


\section{Dalam melaksanakan PAK Keluarga, para orang tua perlu mempunyai} pengetahuan dan karakter hidup yang baik pula. Dengan adanya pengetahuan dan karakter hidup yang baik, orang tua dapat memberikan contoh keteladanan yang baik pula dalam mendidik anak-anaknya. Untuk itu, orang tua perlu mendapat pendampingan dari gereja. Salah satu cara yang dapat dilakukan gereja adalah dengan membuat program mentorship gereja untuk mengajar, mendampingi, membimbing, dan mengarahkan para orang tua agar profesional dalam mendidik anak-anaknya yang sesuai dengan prinsip-prinsip dari ajaran iman Kristen.

Berdasarkan hasil pengamatan peneliti terhadap setiap keluarga di BNKP Jemaat Hiliomasio Medan. Pertama, Pengetahuan para orang mengenai PAK Keluarga masih sangat kurang. Kedua, Pelaksanaan PAK Keluarga dalam jemaat masih belum terlaksanakan dengan maksimal. Ketiga, Kurangnya waktu orang tua dalam melaksanakan PAK keluarga karena sibuk bekerja. Hal-hal tersebut dapat dilihat dari adanya beberapa anak remaja di jemaat BNKP Hiliomasio Medan yang candu dalam penggunaan teknologi, seperti bermain game secara berlebihan, menggunakan media sosial (Facebook, Instagram, Twiter, WhatsApp, dan lainnya) tanpa batas waktu, serta mengakses internet dengan bebas tanpa adanya pengawasan. Akibatnya anak-anak tersebut menjadi malas belajar, malas ke sekolah, malas ke gereja, malas mendengarkan khotbah, tidak kosentrasi dalam beribadah, menurunnya prestasi yang dimiliki anak di sekolah, sering melawan orang tua bila ditegur, suka menyendiri, tidak suka berkomunikasi dengan orang tua, mudah emosi, dan lain-lainnya.

Jika melihat data di atas hanya melalui hasil pengamatan peneliti saja, tentu data yang dirasa masih belum cukup akurat. Oleh karena itu, selain peneliti melakukan pengamatan, peneliti juga melakukan observasi awal dengan melakukan wawancara langsung terhadap beberapa narasumber yang kompeten dalam menjawab permasalahan yang terjadi. Adapun orang-orang yang peneliti wawancara, antara lain, pengurus sekaligus pengajar gereja, pendeta, dan anak-anak remaja yang bergereja di BNKP Jemaat Hiliomasio Medan.

Dalam wawancara langsung dengan pengurus sekaligus pengajar di gereja BNKP Jemaat Hiliomasio Medan (inisial DZ) mengatakan, PAK keluarga di BNKP Jemaat Hiliomasio Medan masih belum terlaksana dengan baik karena masih banyak anak remaja di jemaat yang putus sekolah. Hal ini disebabkan karena faktor orang tua 
yang sibuk dengan pekerjaan mereka dan sebagian dari warga jemaat adalah pekerja bangunan yang berangkat pagi pulang sampai malam hari, sehingga tidak ada waktu untuk memberikan nasehat dan didikan kepada anak-anaknya. Selain itu, ada juga hal lain yang menyebabkan PAK keluarga kurang terlaksana karena kurangnya pengetahuan jemaat tentang pentingnya peran orang tua dalam mendidik anak-anak. Selain itu, pendidikan orang tua sebagian besar hanya memiliki pendidikan rendah (SD/SMP). Kemudian, keteladan para orang tua masih sangat kurang, contohnya masih ada orang tua ketika sedang ibadah, masih asik bermain smartphone-nya.

Dalam wawancara langsung dengan pendeta di gereja BNKP Jemaat Hiiomasio Medan (Inisial Pdt. SZ) mengatakan, pengetahuan orang tua mengenai PAK keluarga di jemaat BNKP Hiliomasio Medan masih sangat kurang karena di dalam gereja masih kekurangan sumber daya manusia (SDM) yang dapat mengajarkan PAK Keluarga kepada jemaat. Selain itu, sebagian orang tua masih mendidik anaknya dengan cara-cara tradisi budaya orang tua pada zamannya, sehingga tidak sesuai dengan konteks mendidik anak remaja pada zaman era digital saat ini. Untuk pelaksanaan PAK Keluarga di jemaat BNKP Hiliomasio juga masih kurang maksimal dilakukan oleh setiap keluarga karena beberapa orang tua juga sibuk bekerja dan beberapa dari mereka masih belum dapat menjadi teladan dalam mendidik anak-anak remajanya, karena setelah mereka pulang bekerja sebagian dari orang tuanya pergi ke lapo tuak. Jadi, bagaimana orang tua mau mendidik anak remajanya supaya memiliki karakter yang baik kalau orang tua sendiri tidak dapat menjadi teladan bagi anak-anaknya.

Selain itu, peneliti juga melakukan wawancara tidak terstruktur kepada 10 orang remaja yang berusia 12-18 tahun di BNKP Jemaat Hiliomasio Medan mengenai pelaksanaan PAK keluarga di dalam keluarga mereka, di mana peneliti menemukan terdapat 1 orang remaja mengatakan, bahwa mereka selalu menerima nasehat dan didikan dari orang tuanya, 7 orang remaja yang mengatakan jarang sekali mendapatkan nasehat dan didikan dari orang tuanya, dan sebanyak 2 orang remaja mengatakan orang tuanya tidak peduli untuk memberikan nasehat dan didikan di dalam keluarganya.

Berdasarkan setiap permasalahan yang ditemui di atas, maka peneliti tertarik untuk melakukan penelitian dengan judul "Mentorship Gereja terhadap PAK Keluarga dalam Membentuk Karakter Remaja Pada Era Digital di BNKP Jemaat Hiliomasio Medan.” Dengan adanya penelitian ini, diharapkan selain bermanfaat untuk gereja 
BNKP Jemaat Hiliomasio Medan, dapat bermanfaat juga bagi gereja-gereja yang sedang mengalami permasalahan yang serupa, serta dapat menjadi acuan bagi para peneliti selanjutnya.

Oleh karena itu, adapun tujuan penelitian ini, yaitu: 1) Untuk mengetahui dan menganalisis bagaimana peran gereja sebagai mentorship terhadap PAK Keluarga di BNKP Jemaat Hiliomasio Medan. 2) Untuk mengetahui dan menganalisis bagaimana pengetahuan orang tua mengenai PAK Keluarga di BNKP Jemaat Hiliomasio Medan. 3) Untuk mengetahui dan menganalisis bagaimana pelaksanaan PAK Keluarga dalam membentuk karakter remaja pada era digital di BNKP Jemaat Hiliomasio Medan.

\section{METODE}

Dalam penelitian ini, menggunakan penelitian kualitatif. Di mana peneliti melakukan proses eksplorasi untuk memahami makna perilaku individu dan kelompok, menggambarkan masalah sosial atau kemanusiaan yang sedang terjadi (Sugiyono, 2013). Dalam penelitian ini, peneliti menggunakan metode pendekatan deskriptif, untuk mempelajari masalah yang ada di lingkungan masyarakat BNKP Jemaat Hiliomasio Medan yang berhubungan dengan kegiatan, sikap, pandangan serta proses yang sedang berlangsung. Dalam pengumpulan data, peneliti melakukan wawancara dan mencari dokumen-dokumen pendukung yang sesuai dengan penelitian ini. Kemudian, peneliti menguji dan memberikan jawaban terhadap masalah yang diangkat (Consuelo $\mathrm{G}$. Sevilla, 2006). Untuk hasil dalam penelitian ini, peneliti mendeskripsikan seluruh keadaan atau gejala yang terjadi, dengan apa adanya, sesuai dengan apa yang terjadi di lingkungan penelitian (Mukhtar, 2013).

Penelitian ini dilaksanakan terhitung dari perencanaan, pelaksanaan, sampai pembuatan laporan. Di mana penelitian ini berlangsung dari bulan April 2020 sampai Januari 2021. Dalam penelitian ini tidak semua jemaat dan pelayanan gereja yang akan menjadi informan, yang berjumlah 789 orang (167 kelapa keluarga). Namun, penelitian ini menggunakan teknik purposive sampling yaitu, melakukan pengambilan sampel dengan beberapa pertimbangan tertentu sehingga mempunyai kriteria khusus sesuai dengan tujuan penelitian, agar hasil yang di dapat representatif dan tidak bias (Sugiyono, 2013). Oleh karena itu, adapun beberapa narasumber yang peneliti sudah tentukan, untuk menjawab latar belakang masalah dalam penelitian ini dan yang sudah 
dapat mewakili keseluruhan jemaat di BNKP Jemaat Hiliomasio Medan, ada sebanyak 10 orang, antara lain: 1 orang pendeta, 3 orang pelayan gereja (pengajar PAK di gereja), dan 6 orang tua yang dapat menjadi perwakilan dalam setiap keluarga, di mana para orang tua juga memiliki anak remaja yang terkena dampak dari perkembangan teknologi sekarang ini.

\section{HASIL DAN PEMBAHASAN}

\section{Mentorship Gereja terhadap PAK Keluarga di BNKP Jemaat Hiliomasio Medan}

Gereja merupakan tempat kehidupan bersama dari sekelompok orang. Kehidupan bersama ini pada dasarnya adalah sebuah realitas sosial yang dipandang sebagai organisasi atau perhimpunan. Istilah organisasi atau perhimpunan gereja biasa dikenal dengan sebutan "persekutuan orang-orang percaya." Sebagai sebuah organisasi, gereja termasuk dalam kategori organisasi keagamaan. Artinya bahwa, gereja merupakan organisasi yang menyajikan nilai-nilai keagamaan berdasarkan ajaran Alkitab (Nugroho, 2019).

Gereja yang merupakan sebuah organisasi tempat perkumpulan orang-orang percaya, mempunyai panggilan yang lebih dikenal dengan Tri tugas gereja, yaitu: koinonia (persekutuan), marturia (kesaksian), dan diakonia (pelayanan). Ketiga hal tersebut saling terkait dan tidak dapat dipisahkan. Dengan kata lain, gereja yang sehat adalah gereja yang mampu menjaga dan melaksanakan tri tugas gereja dalam kehidupan warga jemaatnya. Dalam tri tugas gereja tersebut, adapun yang menjadi salah satu panggilan gereja adalah pelaksanaan Pendidikan Agama Kristen (PAK). PAK merupakan suatu pemberian dan amanat Tuhan kepada gereja. Dalam kitab Efesus 4:11 menjelaskan, Tuhan telah memanggil para anggota gereja, baik rasul-rasul, nabi-nabi, pemberita injil maupun para gembala dan pengajar agar dapat mendidik dan mengajar orang-orang dalam kebenaran (E.G. dan I.H. Enklaar Homrighausen, 2012). Oleh karena itu, Pdt. SH dan pelayan gereja yakni DZ, EW, dan RH mengatakan bahwa, di BNKP Jemaat Hiliomasio Medan sudah mempunyai program untuk menjalankan tri tugas gereja tersebut, khususnya dalam memberikan pengajaran PAK kepada jemaatnya. 
Adanya program PAK dalam sebuah organisasi gereja sangatlah penting, karena dengan adanya pendidikan dan pembinaan, akan membuat gereja semakin berkembang pesat, karena orang-orang yang ada di dalamnya akan semakin bertumbuh dengan iman yang benar (Sianipar et al., 2020) Iman yang benar akan memampukan setiap orang percaya dapat hidup sesuai dengan kebenaran Firman Allah. Di mana Firman Allah mengkehendaki bahwa, agar setiap orang percaya (gereja) dapat menjadi garam dan terang bagi dunia (Mat. 5:13-16; 1 Tes. 5:5; 1 Pet. 2:9; Fil. 2:14-16; Yes. 49:6; Kis. 13:47). Oleh karena itu, mentorship gereja terhadap PAK keluarga, merupakan salah satu program penting yang perlu ada di dalam organisasi gereja.

Adapun pelaksanaan mentorship gereja terhadap PAK keluarga di BNKP Jemaat Hiliomasio Medan, para informan yakni Pdt. SZ dan pelayan gereja DZ, EW, dan RH mengatakan, gereja BNKP sudah mempunyai program tersebut. Namun, program tersebut tidak dibuat secara khusus, maksudnya bahwa gereja sudah memberikan pengajaran tentang PAK keluarga melalui khotbah, PA, dan kegiatan-kegiatan lainnya. Selain itu, gereja juga mempunyai program, ketika ada anak-anak dari jemaat BNKP Hiliomasio Medan yang mempunyai masalah, seperti hamil di luar nikah, narkoba, putus sekolah dan lainnya, lalu orang tuanya melapor kepada gereja, maka gereja akan melakukan pengembalaan kepada orang tuanya dengan cara mengajar, membimbing, dan mendampingi (mentoring) para orang tua agar dapat mendidik anak-anak mereka, kembali ke jalan yang benar.

Berdasarkan informasi di atas dapat dilihat bahwa, pelaksanaan mentorship gereja terhadap PAK keluarga di BNKP Jemaat Hiliomasio Medan masih mempunyai program yang kurang baik. Hal ini sejalan seperti yang dikatakan oleh Pdt. SZ dan Sintua DZ yang mengatakan, masih banyak para orang tua dari jemaat yang memiliki sikap keteladanan yang kurang baik dalam mendidik anak-anaknya. Selain itu, pemahaman para orang tua mengenai PAK keluarga juga masih sangat kurang. Padahal, kalau melihat kembali ke dalam visi, misi, dan strategi BNKP Jemaat Hiliomasio Medan, salah satu pointnya adalah adanya pembinaan keluarga sebagai jantung misi. Dengan demikian, gereja perlu mengkaji kembali dan memberikan perhatian yang lebih terhadap visi, misi, dan strategi yang telah dibuat agar semua yang telah dirancang dapat berjalan dan mencapai tujuannya. 
Selain itu, masih kurang baiknya pelaksanaan mentorship gereja terhadap PAK keluarga di BNKP Jemaat Hiliomasio Medan, terlihat dari tindakan gereja yang hanya memberikan mentoring kepada jemaatnya, apabila para orang tua (jemaat) sudah kewalahan dalam mendidik anak-anaknya dan mau melaporkan kepada gereja, maka gereja akan melakukan tindakan (mentoring) kepada para orang tua tersebut. Hal ini tentu kurang baik bagi pertumbuhan gereja ke depannya, karena semua jemaat (orang tua) tentu memerlukan mentoring dari gereja agar dapat mendidik anak-anaknya sesuai dengan ajaran Firman Tuhan. Oleh karena itu, gereja BNKP Jemaat Hiliomasio Medan perlu mengkaji kembali tentang perannya sebagai mentorship terhadap PAK keluarga. Dengan tujuan, agar gereja tidak hanya memberikan mentoring kepada para orang tua yang mau melaporkan saja, melainkan perlu memberikan mentoring kepada seluruh anggota jemaatnya (orang tua).

Akibat masih kurang baiknya pelaksanaan mentorship gereja terhadap PAK keluarga di BNKP Jemaat Hiliomasio Medan, beberapa keluarga (para orang tua) akhirnya jarang untuk memberikan nasehat dan didikan kepada anak-anaknya (khususnya bagi remaja). Hal ini terlihat dari 10 orang remaja yang peneliti observasi di awal, ada sebanyak 1 orang remaja yang mengatakan, mereka selalu menerima nasehat dan didikan dari orang tuanya, 7 orang remaja mengatakan jarang sekali mendapatkan nasehat dan didikan dari orang tua, dan sebanyak 2 orang remaja mengatakan orang tuanya tidak pernah peduli untuk memberikan nasehat dan didikan di dalam keluarganya. Jadi, lebih banyak remaja yang mengatakan jarang sekali dan tidak pernah mendapatkan nasehat dan didikan dari orang tuanya, daripada remaja yang mengatakan, mereka selalu menerima nasehat dan didikan dari orang tuanya. Di mana hal ini juga sejalan dengan apa yang dikatakan oleh Sintua DZ bahwa, banyak anak remaja dari jemaat yang akhirnya putus sekolah karena kurangnya nasehat dan didikan yang di dapat dari dalam keluarga mereka.

\section{Pengetahuan Orang Tua mengenai PAK Keluarga di BNKP Jemaat Hiliomasio Medan}

Pendidikan Agama Kristen (PAK) adalah pelayanan yang memberikan pondasi pengajaran iman Kristen kepada setiap naradidik. Warner C. Greadorf mengatakan, pendidikan agama Kristen merupakan proses pembelajaran yang 
dilaksanakan berdasarkan ajaran Alkitab, berpusat pada Kristus, dan bergantung terhadap kuasa Roh Kudus yang membimbing (Paulus Lilik Kristianto, 2012). Kemudian, (B. Samuel Sijabat, 1996) mengatakan, adanya pendidikan agama Kristen dapat membentuk kualitas spritual jiwa seseorang akan mempengaruhi dimensi fisik/jasmaninya. Dengan kata lain, PAK dapat mempengaruhi pertumbuhan jasmani dan spritual seseorang agar dapat hidup seturut dengan ajaran Firman Tuhan.

Dari hasil wawancara mengenai pemahaman para orang tua di BNKP Jemaat Hiliomasio Medan tentang pengertian PAK, antara lain: VH mengatakan, sudah pernah tau tetapi sekarang sudah lupa. AH mengatakan, pendidikan agama Kristen adalah mengajarkan pemberitaan Injil sebagaimana yang telah diajarkan Tuhan Yesus. PZ mengatakan, pendidikan agama Kristen adalah tempat anak-anak mengetahui mana yang baik dan yang buruk, di mana dilaksanakan dan diajarkan di gereja, sekolah minggu, dan di keluarga. SH mengatakan, pendidikan agama Kristen adalah pondasi iman yang paling utama dalam memeluk Kekristenan. ST mengatakan, pendidikan agama Kristen adalah pendidikan agama agar kita mengetahui Firman Tuhan.

Berdasarkan tanggapan para informan di tersebut dapat dilihat bahwa, para orang tua di BNKP Jemaat Hiliomasio Medan masih cukup banyak yang kurang memahami arti dari pengertian PAK.

Keluarga Kristen adalah keluarga yang di dalamnya terdiri dari orang-orang yang telah memiliki iman kepercayaan kepada Tuhan Yesus Kristus, sehingga di dalam melaksanakan pendidikan dan pengajaran, harus berdasarkan ajaran dari Firman Tuhan yang ada di dalam Alkitab. (Homrighausen dan Enklaar, 2012) mengatakan, keluarga Kristen merupakan pemberian Tuhan yang tak ternilai harganya. Keluarga Kristen mempunyai peran yang sangat penting dalam pelaksanaan PAK melebihi tugas dan cara-cara yang dilakukan gereja dalam mendidik. Pendapat ini diperkuat oleh (Mark Holmen, 2016) yang mengatakan, keluarga Kristen merupakan tempat utama di dalam menumbuhkan iman seseorang. Oleh karena itu, tujuan dan fungsi utama pendidikan agama Kristen dalam keluarga adalah supaya setiap naradidik yang diajar mengalami proses pertumbuhan ke arah yang lebih dewasa, sesuai dengan ajaran iman Kristen, mampu mengidentifikasi berbagai pergumulan yang ada di dalam keluarga, mampu memahami makna kebersamaan dengan orang lain tanpa harus kehilangan identitasnya sebagai orang Kristen, mampu mewujudkan nilai-nilai Kristiani dalam menghadapi 
gaya hidup modern saat ini, dan mampu mengkritisi perkembangan budaya dan IPTEK (Tafonao, 2018)

Dengan demikian, adapun pengetahuan para orang tua mengenai PAK Keluarga di BNKP Jemaat Hiliomasio Medan. Peneliti menemukan bahwa, sebagian besar para informan mempunyai pengetahuan yang sangat minim mengenai PAK keluarga. VH mengatakan, PAK keluarga sebagai tempat dalam memberitakan pengajaran tentang Tuhan Yesus Kristus bagi anak-anak. DZ, SZ, AH, dan PZ mengatakan, PAK keluarga memiliki tujuan dan fungsi agar setiap orang tua dapat memiliki tanggung jawab untuk mendidik anak-anaknya supaya mengenal Tuhan Yesus Kristus. EW dan RH mengatakan, PAK keluarga untuk mendidik dan mengajar setiap anggota keluarga agar memiliki iman yang kokoh. SH dan ST mengatakan, PAK Keluarga mempunyai tujuan dan fungsi untuk menerapkan Fiman Tuhan di dalam kehidupan keluarga.

\section{Pelaksanaan PAK Keluarga dalam Upaya Membentuk Karakter Remaja Pada Era Digital di BNKP Jemaat Hiliomasio Medan}

Peran orang tua dalam pelaksanaan PAK Keluarga sangatlah penting. Orang tua harus dapat mendidik anak-anaknya agar memiliki pertumbuhan iman yang baik dan memiliki karakter hidup yang sesuai ajaran Firman Tuhan. Adapun peran sebagai orang tua dalam pelaksanaan PAK keluarga dalam upaya membentuk karakter remaja pada era digital di BNKP Jemaat Hiliomasio Medan, antara lain:

Pertama, menanamkan kecerdasan spritual bagi remaja. Usia remaja merupakan usia yang amat potensial dalam perkembangannya (Mohammad Ali, 2010). Untuk itu, menanamkan kecerdasan spritual pada anak usia remaja merupakan waktu yang sangat tepat. James W. Fowler meneliti bahwa, iman pada tahap remaja awal usia 12-15 tahun, pada tahap ini remaja sudah mampu memahami imannya secara lebih rasional. Sedangkan untuk tahap remaja akhir usia 16-18 tahun, remaja sudah mampu bertanggung jawab penuh dengan iman yang telah dipercayainya, baik untuk dirinya maupun orang lain yang ada di sekitarnya (Zega, 2020) Dengan demikian, setiap orang tua perlu untuk memperhatikan pertumbuhan kecerdasan spritual remaja yang sesuai dengan perkembangannya (Ritonga et al., 2021).

Adapun tanggapan para orang tua di BNKP Jemaat Hiliomasio Medan tentang menanamkan kecerdasan spritual bagi remaja, antara lain: semua informan mengatakan 
bahwa, mereka sudah menanamkan kecerdasan spritual bagi anak remajanya. Namun peneliti menemukan bahwa, setiap orang tua memiliki pemahaman dan cara yang berbeda-beda dalam menanamkan kecerdasan spritual tersebut, antara lain: Pdt. SZ dan RH mengatakan, dengan cara setiap pagi dan malam mereka melaksanakan ibadah di mana ada nyanyian, doa, dan perenungan Firman Tuhan secara singkat. DZ dan AH mengatakan, dengan cara mengajarkan anak remaja untuk berdoa dan membaca Alkitab. EW, VH, SZ, dan ST mengatakan, dengan cara mengajarkan kepada anak remaja agar memiliki sikap dan karakter yang baik sesuai dengan ajaran Firman Tuhan. PZ dan SH mengatakan, dengan cara mengajarkan anak remaja agar rajin ke gereja dan selalu berdoa dalam segala hal yang mereka lakukan.

Secara praktis, para orang tua di BNKP Jemaat Hiliomasio Medan sudah berusaha untuk menanamkan kecerdasan spritual bagi setiap anak remaja dengan cara mereka masing-masing, tetapi para orang tua masih belum memperhatikan tahap pertumbuhan kecerdasan spritual dari anak-anak remaja mereka, berdasarkan tingkat usia dan kemampuannya. Hal ini terlihat dari, pemahaman para orang tua yang masih mengajari anak remaja untuk belajar berdoa, membaca Alkitab, rajin beribadah, mengajari hal-hal untuk berbuat baik, dan lainnya. Padahal seharusnya anak yang memasuki usia remaja, para orang tua sudah dapat mengajak remaja agar lebih berpikir kritis tentang iman yang telah diyakinikinya, sehingga ketika anak sudah memasuki usia remaja akhir, remaja sudah benar-benar dapat mempertanggungjawabkan iman yang diyakininya, baik bagi dirinya maupun untuk lingkungan sekitarnya.

Kedua, menjadi contoh dan teladan dalam bersikap. (Jarot Wijanarko, 2018) mengatakan, orang tua adalah contoh bagi remaja dalam bersikap. Para orang tua seringkali tidak menyadari bahwa setiap perilaku remaja dipengaruhi oleh cara didikan dari orang tuanya. Orang tua adalah panutan bagi remaja, jika orang tua tidak memiliki keteladanan yang baik, maka remaja akan mudah terjerumus ke dalam berbagai pergaulan yang salah. Untuk itu, orang tua harus dapat menjadi contoh teladan yang baik bagi setiap anak remajanya.

Adapun tanggapan para orang tua di BNKP Jemaat Hiliomasio Medan tentang menjadi contoh dan teladan yang baik dalam bersikap. Ada sebanyak $60 \%$ informan yang mengatakan, sudah menjadi teladan yang baik dalam bersikap. Ada sebanyak $30 \%$ yang masih ragu-ragu bahwa dirinya sudah menjadi teladan. Ada sebanyak 10\% yang 
mengatakan, masih kurang atau belum menjadi teladan di dalam keluarganya. Jadi, dapat diketahui bahwa, ada sebanyak 60\% informan yang mengatakan benar-benar yakin bahwa dirinya sudah menjadi teladan. Namun, sebagian dari $60 \%$ tersebut ada yang baru selesai merokok dan ada juga yang baru selesai minum tuak, dan sedang membahas togel di dalam rumahnya. Jadi, sesungguhnya peneliti menemukan bahwa, masih kurang dari 60\% para orang tua di BNKP Jemaat Hiliomasi Medan yang benarbenar sudah menjadi contoh dan teladan yang baik dalam kehidupan rumah tangganya. Hal ini sejalan dengan tanggapan Pdt. SZ yang mengatakan, beberapa orang tua jemaat masih belum dapat menjadi teladan dalam mendidik anak-anak remajanya, karena setelah mereka pulang bekerja sebagian dari orang tuanya pergi ke lapo tuak.

Bagaimana mereka mau mendidik anak remajanya supaya memiliki karakter yang baik kalau orang tua sendiri tidak dapat menjadi teladan bagi anak-anaknya.

Ketiga, membangun komunikasi yang baik dengan remaja seperti seorang sahabat. Pada era digital saat ini, sesungguhnya orang tua dapat dengan mudah menjalin komunikasi yang baik dengan anak remajanya. Karena orang tua dapat memanfaat kecanggihan teknologi, agar tetap bisa berkomunikasi meskipun dalam jarak yang jauh. Setidaknya orang tua dapat menggunakan media sosial seperti: whatsapp, messenger, facebook, twitter, dan lainnya, sehingga orang tua tidak hanya berkomukasi kepada anak remaja dalam dunia nyata, melainkan juga dapat berkomunikasi dalam media sosial yang biasa digunakan oleh remaja (Tafonao, 2018) Dengan adanya komunikasi yang baik antara orang tua dan remaja, orang tua akan semakin mudah untuk mengetahui dan membantu remaja dalam mengatasi setiap permasalahan yang sering dihadapinya. Selain itu, dengan bantuan teknologi yang canggih saat ini, orang tua dapat setiap saat untuk memberikan nasehat agar mengingatkan remaja selalu untuk mengandalkan Tuhan dalam kehidupannya.

Adapun tanggapan para orang tua di BNKP Jemaat Hiliomasio Medan tentang membangun komunikasi yang baik dengan remaja seperti seorang sahabat, antara lain: ada sebanyak $70 \%$ informan yang mengatakan, sudah yakin memiliki komunikasi yang baik dengan anak-anak remajanya. Ada sebanyak 20\% informan yang masih ragu bahwa dirinya sudah memiliki komunikasi yang baik dengan anak remajanya, dan ada sebanyak 10\% informan yang mengatakan, masih kurang atau belum memiliki komunikasi yang baik dengan anak remajanya. Jadi, dapat dilihat bahwa, ada cukup 
banyak (70\%) orang tua di BNKP Jemaat Hiliomasio Medan yang mengatakan bahwa, diri mereka sudah memiliki komunikasi yang baik dengan anak-anak remajanya.

Keempat, peduli akan setiap permasalahan yang dihadapi remaja dalam masa pertumbuhannya. Di dalam ajaran Alkitab, anak adalah pemberian Tuhan yang tidak ternilai harganya. Dengan demikian, orang tua perlu menghargai pemberian Allah tersebut, di mana tugas tanggung jawab orang tua adalah melindungi, menjaga, merawat, dan membesarkan anak-anak tersebut agar bertumbuh menjadi seseorang yang dapat mempermuliakan Allah dalam kehidupannya (Mzm. 150:1; Mat. 4:20; Ibr. 12:2829, 13:15; Rom. 12:1; Yoh. 4:23-24; Kol. 3:16). Oleh karena itu, agar remaja dapat bertumbuh sesuai dengan ajaran Alkitab, orang tua Kristen perlu memberikan kepedulian terhadap setiap permasalahan yang dihadapi oleh anak remajanya, agar mereka tidak terjerumus ke dalam perilaku-perilaku yang dapat merusak pertumbuhan karakternya (Setiasih, 2012).

Adapun tanggapan para orang tua di BNKP Jemaat Hiliomasio Medan tentang peduli terhadap permasalahan yang dihadapi remaja dalam masa pertumbuhannya, antara lain: ada sebanyak 90\% informan yang mengatakan bahwa mereka benar-benar peduli atas setiap permasalahan yang dihadapi oleh anak remajanya. Rasa kepedulian para informan terhadap anak remajanya sebagai berikut: Pdt. SZ mengatakan, ketika anak remaja kami memiliki masalah akan kelihatan dari sikapnya, maka di situ saya sering menanyakan apa masalah yang mereka sedang hadapi. EW mengatakan, saya peduli dan permasalahan yang sering kami hadapi dalam mendidik anak-anak remaja, contohnya tentang keluar dari rumah melewati batas waktu yang diberikan dan anakanak yang sangat bebas dalam menggunakan handphonenya. RH mengatakan, peduli dan salah satu permasalahan yang sering kami hadapi dalam mendidik anak remaja yaitu tidak terkontrolnya ketika bermain handphone, pergaulan dengan teman sebayanya yang tidak baik, dan pergaulan dengan lingkungan yang tidak memiliki sopan santun. VH mengatakan, salah satu bentuk kepedulian saya dengan cara menasehati mereka agar mengikuti perilaku yang baik dan jangan mengikuti perilaku yang tidak baik. SZ mengatakan, peduli, masalah yang paling sering terjadi kepada anak-anak remaja kami soal bermain game di handphone tetapi kami sudah memberikan nasehat kepada mereka. AH mengatakan, saya peduli contohnya kalau mereka mau pergi ke manapun mereka harus ijin. PZ, SH, dan ST mengatakan, saya sering 
memperhatikan anak-anak jika keluar rumah dan permasalahan yang paling sering saya hadapi seperti mereka yang suka keluar malam untuk nongkrong-nongkrong, merokok, dan kalau menggunakan handphone untuk bermain game tanpa melihat waktu.

Berdasarkan tanggapan para informan di atas, peneliti menemukan bahwa para orang tua di BNKP Jemaat Hiliomasio Medan sebenarnya mempunyai rasa kepedulian terhadap anak-anak remajanya. Namun walaupun demikian, para orang tua masih kurang dapat mengontrol kelakuan anak-anak remajanya karena kurangnya pemahaman dan pengetahuan para orang tua, akan bagaimana cara mendidik remaja yang sesuai dengan kebutuhannya di era digital saat ini.

Kelima, memberikan motivasi dan dukungan ke arah yang positif terhadap pertumbuhan remaja. Orang tua yang dapat memberikan motivasi dan dukungan yang positif bagi remaja, akan membuat remaja merasa memiliki orang tua yang selalu menerima kelebihan dan kekurangannya (Tafonao, 2018). (Sumara et al., 2017) menjelaskan, orang tua perlu memberi motivasi dan dukungan kepada remaja untuk menyalurkan energinya dalam berbagai kegiatan yang positif, seperti berolahraga, melukis, mengikuti perlombaan, dan penyaluran hobi. Dengan memberikan dukungan kepada remaja untuk melakukan berbagai kegiatan tersebut, remaja akan terhindar dari pergaulan bebas yang tidak diinginkan. Selain itu, kemampuan atau bakat yang dimiliki remaja juga akan semakin berkembang, sehingga bermanfaat, baik bagi dirinya maupun orang-orang yang ada disekelilingnya.

Adapun tanggapan para orang tua di BNKP Jemaat Hiliomasio Medan tentang memberikan motivasi dan dukungan ke arah yang positif terhadap pertumbuhan remaja, antara lain: semua informan mengatakan sudah yakin bahwa, sebagai orang tua mereka sudah memberikan motivasi dan dukungan ke arah yang positif bagi anak remajanya. Beberapa motivasi dan dukungan yang telah diberikan oleh para orang tua seperti, mendukung remaja untuk mengembangkan kemampuan/talentanya, mendukung remaja menjadi pribadi yang sukses, dan mendukung remaja agar hidup sesuai dengan ajaran Firman Tuhan. Menurut peneliti hal-hal tersebut tentulah sangat baik, tetapi para orang tua di BNKP Jemaat Hiliomasio Medan harus benar-benar serius dalam memberikan motivasi dan dukungan seperti yang mereka telah ungkapkan, sehingga kedepannya apa yang diharapkan oleh para orang tua terhadap anak remajanya, tidak hanya menjadi sebuah angan-angan saja. 
Keenam, menciptakan lingkungan keluarga yang harmonis. Lingkungan keluarga yang harmonis sangat mempengaruhi pembentukan karakter remaja yang positif. Seperti yang diungkap oleh (Suharnan, 2014) bahwa, semakin tinggi tingkat keharmonisan di dalam keluarga, membuat semakin rendahnya kenakalan remaja. Kebutuhan psikologis ini akan didapatkan remaja dari lingkungan keluarga yang harmonis. Dalam lingkungan keluarga yang harmonis, seluruh anggota keluarga merasa dicintai, dan mencintai, merasa terpenuhi kebutuhan biologis dan psikologisnya, saling menghargai dan mengembangkan sistem interaksi yang memungkinkan setiap anggota dapat mengembangkan seluruh potensi dan kemampuannya.

Adapun tanggapan para orang tua di BNKP Jemaat Hiliomasio Medan tentang menciptakan lingkungan keluarga yang harmonis, antara lain: ada sebanyak 70\% informan yang mengatakan, sudah benar-benar yakin bahwa keluarganya sudah hidup harmonis dan ada sebanyak 30\% informan yang mengatakan, belum terlalu harmonis. Di mana RH mengatakan, menurutnya keluarga mereka masih belum harmonisharmonis sekali karena masih ada masalah-masalah yang sering terjadi di dalam keluarganya. PZ mengatakan, di dalam keluarga kami kadang ada pertengkaran dan pertengkaran tersebut terkadang terjadi di depan anak, ST mengatakan, harmonis tetapi tergantung ekonomi. Jadi, peneliti menemukan bahwa, masih ada beberapa keluarga di BNKP Jemaat Hiliomasio Medan yang kehidupan keluarganya masih belum cukup harmonis.

Ketujuh, memberikan aturan dan pengawasan bagi remaja terhadap penggunaan teknologi yang mereka gunakan. (Jarot Wijanarko, 2018) mengatakan, Tuhan memberi ajaran dan aturan untuk mendidik umat-Nya supaya taat dan tidak hidup semaunya. Demikian halnya dengan orang tua perlu membuat aturan terhadap remaja supaya memiliki kedewasaan, etika, dan sopan santun yang sesuai dengan ajaran Firman Tuhan. Dengan kata lain, orang tua pada era digital saat ini, perlu untuk memberikan aturan dan pengawasan bagi setiap anak remaja agar dapat menggunakan teknologi dengan bijak.

Adapun tanggapan para informan di BNKP Jemaat Hiliomasio Medan tentang memberikan aturan dan pengawasan bagi anak remaja terhadap penggunaan teknologi, antara lain: ada sebanyak $40 \%$ informan yang mengatakan, sudah memberikan aturan dan pengawasan, informan tersebut yaitu, Pendeta dan para pengajar di gereja, sedangkan informan dari para jemaat (orang tua yang memiliki anak remaja) ada 
sebanyak 30\% informan yang mengatakan, hanya memberikan pengawasan saja bagi anak remajanya, dan ada sebanyak 30\% informan yang mengatakan, mereka masih belum memberikan aturan dan pengawasan bagi anak-anak remajanya dalam penggunaan alat-alat teknologi yang ada di dalam keluarga.

Jadi, dapat disimpulkan bahwa, ada sebanyak 60\% para orang tua di BNKP Jemaat Hiliomasio Medan yang masih belum membuat aturan di dalam keluarganya, khususnya tentang penggunaan teknologi. Padahal masalah yang paling sering dihadapi oleh para orang tua adalah anak-anak remaja yang tidak bisa dibatasi dalam penggunaan handphone. Handphone memang sangat banyak fungsi dan manfaatnya, tetapi dapat berakibat buruk terhadap pembentukan karakter remaja, apabila teknologi tersebut disalahgunakan. Dengan demikian, agar hal-hal tidak diinginkan terjadi terhadap anakanak remaja di BNKP Jemaat Hiliomasio Medan, sebaiknya para orang tua perlu untuk membuat aturan dan melakukan pengawasan terhadap penggunaan handphone, khususnya internet dan situs-situs yang diakses oleh anak-anak remajanya.

\section{SIMPULAN}

Berdasarkan rumusan masalah dalam penelitian ini, maka kesimpulannya adalah: 1) mentorship PAK keluarga di BNKP Jemaat Hiliomasio Medan, masih memiliki peran yang kurang baik. 2) pengetahuan orang tua mengenai PAK Keluarga sangat minim mengenai tujuan dan fungsi PAK Keluarga. 3) pelaksanaan PAK Keluarga dalam upaya membentuk karakter remaja pada era digital, antara lain : Pertama, para orang tua masih belum memperhatikan tahap pertumbuhan kecerdasan spritual dari anak-anak remaja mereka, berdasarkan tingkat usia dan kemampuannya. Kedua, masih kurang dari 60\% para orang tua yang benar-benar sudah menjadi contoh dan teladan yang baik dalam kehidupan keluarganya. Ketiga, ada cukup banyak (70\%) orang tua yang mengatakan, diri mereka sudah memiliki komunikasi yang baik dengan anak-anak remajanya. Keempat, orang tua masih kurang dapat mengontrol kelakuan anak-anak remajanya, karena kurangnya pemahaman orang tua, akan bagaimana cara mendidik remaja yang sesuai dengan kebutuhannya di era digital saat ini. Kelima, para orang tua sudah memberikan motivasi dan dukungan ke arah yang positif bagi anak remajanya. Keenam, masih ada beberapa keluarga yang masih belum memiliki 
kehidupan yang cukup harmonis dalam menjalani kehidupan rumah tangganya. Ketujuh, ada sebanyak $60 \%$ orang tua yang masih belum membuat aturan di dalam keluarganya.

Berdasarkan kesimpulan di atas, maka ada beberapa saran yang dapat diberikan kepada gereja BNKP Jemaat Hiliomasio Medan dan para pelayan gereja (pengajar PAK), yaitu: Pertama, saran kepada gereja BNKP Jemaat Hiliomasio Medan, 1) gereja perlu untuk membuat program yang dirancang dan disusun secara sistematis dalam mementoring jemaatnya, khususnya mengenai pelaksanaan PAK keluarga. 2) gereja perlu untuk memberikan perhatian lebih terhadap pengajaran mengenai PAK kepada anggota jemaat, khususnya mengenai arti PAK keluarga, fungsi dan tujuan PAK keluarga, serta landasan Alkitabiah PAK keluarga. 3) Pelaksanaan PAK Keluarga dalam membentuk karakter remaja masih cukup lemah. Oleh karena itu, gereja perlu untuk memberikan perhatian yang lebih kepada para orang tua, agar dapat menanamkan kecerdasan spritual bagi remaja yang sesuai dengan pertumbuhan dan perkembangannya, dapat memiliki contoh dan teladan yang baik dalam dalam kehidupan rumah tangganya, memiliki komunikasi yang baik dengan anak-anak remajanya, peduli terhadap setiap permasalahan yang dihadapi oleh remaja dalam masa pertumbuhannya, memberikan motivasi dan dukungan yang positif terhadap pertumbuhan remaja, menciptakan lingkungan keluarga yang harmonis, dan dapat memberikan aturan dan pengawasan bagi anak remaja, khususnya dalam penggunaan teknologi. Kedua, saran kepada para pelayan gereja (pengajar PAK), 1) perlu untuk dapat meng-upgrade kemampuan diri agar dapat mengajarkan PAK keluarga yang sesuai dengan kebutuhan jemaat, 2) perlu dapat memahami situasi lingkungan dan keadaan setiap jemaat, sehingga dapat mengetahui permasalahan yang sering dihadapi jemaatnya, khususnya pada era digital saat ini, dan 3) perlu untuk memberikan mentoring bagi para orang tua (jemaat) agar dapat mendidik anak-anaknya, sehingga memiliki pembentukan karakter yang sesuai dengan ajaran iman Kristen.

\section{DAFTAR PUSTAKA}

Ali, M. (2010). Psikologi Remaja Perkembangan Peserta Didik. Bumi Aksara. Basyari, I. (2019). Sebagian Kasus Kenakalan Remaja Dipicu Media Sosial. Www.Kompas.Id.

Haryanto, A. T. (2020). Riset: Ada 175, 2 Juta Pengguna Internet Di Indonesia. Inet.Detik.Com. 
Holmen, M. (2016). Church + Home. Pionir Jaya.

Homrighausen, E. G. Dan I. H. E. (2012). Pendidikan Agama Kristen. Bpk Gunung Mulia.

Kristianto, P. L. (2012). Prinsip Dan Praktik Pendidikan Agama Kristen. Andi.

Mukhtar. (2013). Metode Penelitian Deskriptif Kualitatif. Referensi-Gp.

Nugroho, F. J. (2019). Gereja Dan Kemiskinan: Diskursus Peran Gereja Di Tengah Kemiskinan. Evangelikal: Jurnal Teologi Injili Dan Pembinaan Warga Jemaat, $3(1), 100-112$.

Ratnaya, I. G. (2011). Dampak Negatif Perkembangan Terknologi Informatika Dan Komuniakasi Dan Cara Antisifasinya. Jurnal: Jptk, Undiksha, 8(1), 23-25.

Ritonga, N., Mone, J. L. T., Yunip, M., \& Zega, Y. K. (2021). Implementasi Metode Problem Solving Dalam Meningkatkan Pembelajaran Pendidikan Agama Kristen Di Sekolah. Jurnal Shanan, 5(1), 29-42. Https://Doi.Org/10.33541/Shanan.V5i1.2622

Ritonga, N., \& Rantung, D. A. (2018). Evaluasi Implementasi Pak Keluarga Di Gkri Jemaat Diaspora Cawang Jakarta Timur. Jurnal Shanan, 2(2), 110-111. Https://Doi.Org/10.33541/Shanan.V2i2.1538

Setiasih. (2012). Menjadi Seorang Sahabat. In Permasalahan Psikologi Perkotaan Dan Solusinya (Pp. 174-176). University Of Surabaya.

Setiawan, W. (2017). Era Digital Dan Tantangannya (Issue Seminar Nasional Pendidikan). Universitas Pendidikan Indonesia.

Sevilla, C. G. (2006). Pengantar Metode Penelitian. Universitas Indonesia.

Sianipar, D., Zega, Y. K., Nehe, L., \& Kristiantoro. (2020). Pelatihan Penyusunan Kurikulum Pendidikan Agama Kristen Remaja Di Hkbp Jatisampurna Bekasi. Jurnal Comunitã Servizio: Jurnal Terkait Kegiatan Pengabdian Kepada Masyarakat, Terkhusus Bidang Teknologi, Kewirausahaan Dan Sosial Kemasyarakatan, 2(2), 447-457. Https://Doi.Org/10.33541/Cs.V2i2.1964

Sijabat, B. S. (1996). Strategi Pendidikan Kristen. Andi Offset.

Sugiyono. (2013). Cara Mudah Menyusun: Skripsi, Tesis Dan Desertasi. Alfabeta.

Suharnan, M. Dan. (2014). Keharmonisan Keluarga, Konsep Diri Dan Kenakalan Remaja. Persona, Jurnal Psikologi Indonesia, 3(2), 154-164.

Sulistyo, P. D. (2019). Media Sosial Berperan Picu Perundungan. Www.Kompas.Id.

Sumara, D., Humaedi, S., \& Santoso, M. B. (2017). Kenakalan Remaja Dan Penanganannya. Jurnal Penelitian \& Ppm, 4(2), 129-389.

Tafonao, T. (2018). Peran Pendidikan Agama Kristen Dalam Keluarga Terhadap Prilaku Anak. Edudikara: Jurnal Pendidikan Dan Pembelajaran, Vol.3(No.2), 129-131.

Wicaksono, W. M. (2019). Bolos Massal 71 Pelajar Smk Dari Bogor Ditahan Di Polres Banyumas. Www.Kompas.Id.

Wijanarko, J. (2018). Mendidik Anak Dengan Hati. Keluarga Indonesia Bahagia.

Zega, Y. K. (2020). Teori Perkembangan Iman Remaja Menurut James W. Fowler Dan Implikasinya Bagi Pendidikan Agama Kristen. Jurnal Pendidikan Dan Kebudayaan Missio, 12(2), 140-151. Https://Doi.Org/10.36928/Jpkm.V12i2.488 


\section{Wawancara :}

Pdt. Salena Zega, S.Th. (Inisial Pdt. Sz), "Pendeta Di Gereja Bnkp Hiliomasio Medan," Wawancara Senin, 9 November 2020, Pukul 11:00-12:15 Wib.

Rosdiana Harefa, Se. (Inisial Rh), "Sekretaris Dan Pengajar Di Gereja Bnkp Hiliomasio Medan," Wawancara Rabu, 18 November 2020, Pukul 19:00-20:15 Wib.

Desdanillah Zebua, S.Pd.K (Inisial Dz), "Sintua Dan Pengajar Di Gereja Bnkp Hiliomasio Medan,’Wawancara Senin, 09 November 2020, Pukul 14:00-15:00 Wib.

Drs. Sokhinaso Harefa (Inisial Sh), "Pengurus Pertama Di Gereja Bnkp Jemaat Hiliomasio Medan," Wawancara Rabu 11 November 2020, Pukul 19:00-19:30 Wib.

Elinuddin Waruwu (Inisial Ew), "Ketua Badan Pekerja Majelis Jemaat (Bpmj) Dan Pengajar Di Gereja Bnkp Hiliomasio Medan," Wawancara Senin, 16 November 2020, Pukul 18:30-20:15 Wib.

Kel. A/I Albert Harefa (Inisial Ah), “Anggota Jemaat Gereja Bnkp Jemaat Hiliomasio Medan," Wawancara Rabu, 11 November 2020, Pukul 19:30-20:30 Wib.

Kel. A/I Pilip Zebua (Inisial Pz), "Anggota Jemaat Di Gereja Bnkp Jemaat Hiliomasio Medan,” Wawancara Minggu, 15 November 2020, Pukul 16:00-17:00 Wib.

Kel. A/I Sandi Telaumbanua (Inisial St), “Anggota Jemaat Di Gereja Bnkp Jemaat Hiliomasio Medan,” Wawancara Rabu, 18 November 2020, Pukul 20:45-21:30 Wib.

Kel. A/I Septa Hulu (Inisial Sh), “Anggota Jemaat Di Gereja Bnkp Jemaat Hiliomasio Medan," Wawancara Minggu, 15 November 2020, Pukul 17:00-18:00 Wib.

Kel. A/I Vebta Hulu (Inisial Vh), "Anggota Jemaat Di Gereja Bnkp Jemaat Hiliomasio Medan," Wawancara Senin, 09 November 2020, Pukul 16:00-18:00 Wib.

Kel. A/I. Susi Zega (Inisial Ah), "Anggota Jemaat Di Gereja Bnkp Jemaat Hiliomasio Medan,” Wawancara Selasa, 10 November 2020, Pukul 18:30-20:00 Wib. 